\title{
DIFFICULTIES IN DIFFERENTIAL DIAGNOSIS OF CUTANEOUS MANIFESTATIONS IN PATIENTS WITH CORONAVIRUS INFECTION
}

Tairova $\mathrm{RT}^{1,2}$, Gaydina $\mathrm{TA}^{1,2} \square$, Dvornikov $\mathrm{AS}^{2}$, Tazartukova $\mathrm{AD}^{1}$, Lyang $\mathrm{OV}^{1}$

${ }^{1}$ Federal Center for Brain Research and Neurotechnology of FMBA, Moscow, Russia

2 Pirogov Russian National Research Medical University, Moscow, Russia

\begin{abstract}
Patients with severe SARS-CoV-2 infection (COVID-19) and multiple comorbidities should be monitored for possible adverse reactions to prescribed drugs, including drug eruptions (DE) at any stage of treatment. Below, we describe a clinical case of a 92-year-old female patient with severe PCR-confirmed COVID-19. The patient was treated with amoxicillin/clavulanic acid, moxifloxacin, acetylcysteine, and sodium enoxaparin. On day 9 into treatment, the patient developed moderately itching macular rashes showing a tendency to coalesce, but overall showed no signs of deterioration. On day 15 , the rashes regressed, following a short course of dexamethasone and chloropyramine. This kind of skin reaction might have been provoked by $\beta$-lactams and fluoroquinolones included in the treatment regimen, a secondary bacterial infection, compromised immunity due to advanced age, and high viral load associated with dermatological symptoms. Delayed onset of skin symptoms might be regarded as a marker of COVID-19 severity.
\end{abstract}

Keywords: coronavirus infection, skin manifestations, toxidermia, drug eruptions

Author contribution: Tairova RT, Gaydina TA: interpretation of the obtained data, manuscript draft; Dvornikov AS: literature analysis; Tazartukova AD: interpretation of the obtained data; Lyang OV: manuscript draft.

Compliance with ethical standards: the patient gave informed consent to medical treatment and publication of this case report.

$\square$ Correspondence should be addressed: Tatiana A. Gaydina

Ostrovityanova, 1, Moscow, 117997; doc429@yandex.ru

Received: 23.09.2020 Accepted: 08.10.2020 Published online: 20.10.2020

DOI: $10.24075 /$ brsmu.2020.062

\section{СЛОЖНОСТИ ДИФФЕРЕНЦИАЛЬНОЙ ДИАГНОСТИКИ КОЖНЫХ ПРОЯВЛЕНИЙ ПРИ КОРОНАВИРУСНОЙ ИНФЕКЦИИ}

\author{
Р. Т. Таирова ${ }^{1,2}$, Т. А. Гайдина ${ }^{1,2}$, А. С. Дворников², А. Д. Тазартукова ${ }^{1}$, О. В. Лянг \\ ${ }_{1}^{1}$ Федеральный центр мозга и нейротехнологий Федерального медико-биологического агентства, Москва, Россия \\ 2 Российский национальный исследовательский медицинский университет имени Н. И. Пирогова, Москва, Россия
}

\begin{abstract}
При лечении мультиморбидных пациентов с тяжелым течением новой коронавирусной инфекции, вызванной вирусом SARS-CoV-2 (COVID-19), необходимо проявлять внимание к возможному развитию лекарственной экзантемы (ЛЭ) в любой период времени лечения. Представлено клиническое наблюдение больной 92 лет с тяжелым течением подтвержденного ПЦР COVID-19. На фоне лечения амоксициллином/клавулановой кислотой, моксифлоксацином, ацетилцистеином, омепразолом, эноксапарином натрия на 9-й день лечения появились умеренно зудящие макулезные высыпания с тенденцией к слиянию без отрицательной динамики соматического статуса. На 15-й день лечения на фоне приема дексаметазона и хлоропирамина кожные высыпания регрессировали. Появление сыпи может быть обусловлено применением $\beta$-лактамных антибактериальных препаратов и фторхинолонов, присоединением бактериальной инфекции и иммунносупрессивным статусом пациентки старческого возраста, а также высокой вирусной нагрузкой, ассоциированной с появлением дерматологических симптомов. Отсроченное появление кожных изменений на фоне COVID-19 возможно рассматривать как «маркер» тяжести заболевания.
\end{abstract}

Ключевые слова: коронавирусная инфекция, кожные проявления, токсидермия, лекарственная экзантема

Вклад авторов: Р. Т. Таирова, Т. А. Гайдина - интерпретация данных, подготовка черновика рукописи; А. С. Дворников - анализ литературы; А. Д. Тазартукова - интерпретация данных; О. В. Лянг — подготовка черновика рукописи.

Соблюдение этических стандартов: пациентка подписала добровольное информированное согласие на лечение и публикацию данных.

$\varnothing$ Для корреспонденции: Татьяна Анатольевна Гайдина

ул. Островитянова, д. 1, г. Москва, 117997; doc429@yandex.ru

Статья получена: 23.09.2020 Статья принята к печати: 08.10.2020 Опубликована онлайн: 20.10.2020

DOI: $10.24075 /$ vrgmu.2020.062

The etiology of exanthems afflicting patients with the coronavirus infection (CVI) caused by SARS-CoV-2 (COVID-19) can pose a diagnostic challenge [1-3], especially during the ongoing epidemic, when clinicians are required to follow physical distance guidelines and wear personal protective equipment while examining the skin and the oral mucosa of patients with COVID-19 [2, 4].

It is vital that comorbid patients with severe CVI undergoing systemic combination therapy for the viral infection should continue receiving their usual medicines for preexisting conditions [5]. Effective pharmacotherapeutic strategies for $\mathrm{CVI}$ must account for such comorbidities and possible adverse reactions to anti-CVI therapy, the most common being cutaneous drug eruptions (DE). The diagnosis of DE can be difficult, especially at onset. Establishing a causal link between
DE and a specific drug is even more challenging if the treatment regimen includes more than one medication [6-8].

Since the beginning of the pandemic, a variety of skin manifestations have been reported in patients with COVID-19; however, specific skin symptoms that would help in verifying the diagnosis of COVID-19 are yet to be identified [1, 9-11]. Skin manifestations observed in patients with CVI should be thoroughly studied, systematized and analyzed for the possible association with the severity of the infection.

\section{Clinical case}

A female patient $\mathrm{C}$. aged 92 years had acute-onset symptoms, including cough, weakness and increased body temperature 
$\left(37.8^{\circ} \mathrm{C}\right)$, followed by sudden deterioration, shortness of breath and febrile chills two days later. The patient was taken to hospital by an EMS team. She denied any contact with individuals showing symptoms of acute respiratory infection suggestive of COVID-19 in the preceding 14 days. The patient shares a flat with her niece, who had no health complaints at the time of her aunt's illness. The history of preexisting conditions included elevated blood pressure, coronary artery disease, long-standing persistent atrial fibrillation, and gallstone disease. The patient denied any allergies or drug intolerance.

On admission, the patient's condition was assessed as severe. Her skin color was normal, and visible mucous membranes showed no signs of dryness. No discoloration of the sclera was observed. Peripheral lymph nodes were unremarkable. The patient was not edematous. Her chest was symmetrical and cylinder-shaped. $\mathrm{SpO}_{2}$ was $70 \%$, increasing to $95 \%$ after oxygen insufflation at $10 \mathrm{~L} / \mathrm{min}$. Cardiac and lung auscultation was not performed due to the risk of SARS-CoV-2 spread. BP was 160/80 mmHg; heart rate was 80 beats $/ \mathrm{min}$. The abdomen was soft without tenderness. The liver was not enlarged. There were no signs of peritoneal irritation. The patient described her bowel movement as regular. The kidney percussion test was negative on both sides. The patient denied dysuria. Neurological examination was unremarkable.

The subsequent CT scan was suggestive of communityacquired polysegmental viral pneumonia and interstitial pulmonary edema, indicating the onset of hemodynamic compromise. Blood count: white blood cells $9.7 \times 10^{9} / \mathrm{L}$; absolute and relative lymphocyte counts $0.7 \times 10^{9} / \mathrm{L}$ and $7.2 \%$, respectively, indicating lymphopenia; relative monocyte count $1.3 \%$ (relative monocytopenia); absolute and relative granulocyte counts $8.9 \times 10 \%$ and $91.5 \%$, respectively (granulocytosis). Blood biochemistry: elevated C-reactive protein (67 mg/L), AST 56 un/L, ALT 41 un/L, D-dimer 1817 ng/ml.

The patient's nasopharyngeal swab tested positive for SARS-CoV-2 RNA. The test was conducted using a reagent kit for RT-PCR-based detection of SARS-CoV-2/SARS-CoV RNA in human specimens (DNA-Technology TS; Russia).

Biological specimens for PCR analysis were collected from the patient's nasopharynx.

Viral RNA was manually extracted from $400 \mu$ of the biological specimens using a Proba-NK reagent kit (DNATechnology; Russia) and eluted in $50 \mu \mathrm{L}$ of an RNA buffer.

The SARS-CoV-2/SARS-CoV RT-PCR reagent kit (DNATechnology TS; Russia) is designed to target 3 viral genome regions: those specific to SARS-CoV-2 (the Cy5/Red detection channel), the E gene regions (the Rox/Orange detection channel), and the conserved region of the E gene (the Fam/Green detection channel) common to the group of SARS-CoV-like coronaviruses, including SARS-CoV and SARS-CoV-2.

The kit contains a heterologous amplification system (Internal Control, or IC, detectable in the Hex/Yellow channel) for monitoring RT-PCR inhibition and checking the integrity of the reagents. The kit includes a positive control. The assay was run in a DTprime thermocycler (DNA-Technology; Russia).

In total, 4 specimens were studied; the specimens were collected on May 28, 2020, June 3, June 9, and June 16.

For the sample collected on May 28, an early exponential increase in fluorescence was detected in the Fam/Green channels (the conserved region of the $E$ gene; Fig. 1), with $\mathrm{Ct}=24.6$, indicating the presence of SARS-CoV RNA.

In the Rox/Orange detection channel (the E gene of SARSCoV-2; Fig. 2), the Ct value was 24.5

In the Cy5/Red detection channel (the $\mathrm{N}$ gene of SARSCoV-2; Fig. 3), the Ct value was 23.9, indicating the presence of SARS-CoV-2 RNA.

Given that valid negative and positive controls were used in the assay, the absence of fluorescence in the Hex/ellow channel (Fig. 4) indirectly suggested high SARS-CoV-2 RNA levels in the studied sample. For the sample collected on June 3 (day 7 ), an increase in fluorescence intensity was observed in the Fam/Green channel (SARS-CoV RNA), with $\mathrm{Ct}=37.4$; the Hex/Yellow $(\mathrm{IC})$ channel, with $\mathrm{Ct}=31.0$; the Rox/Orange
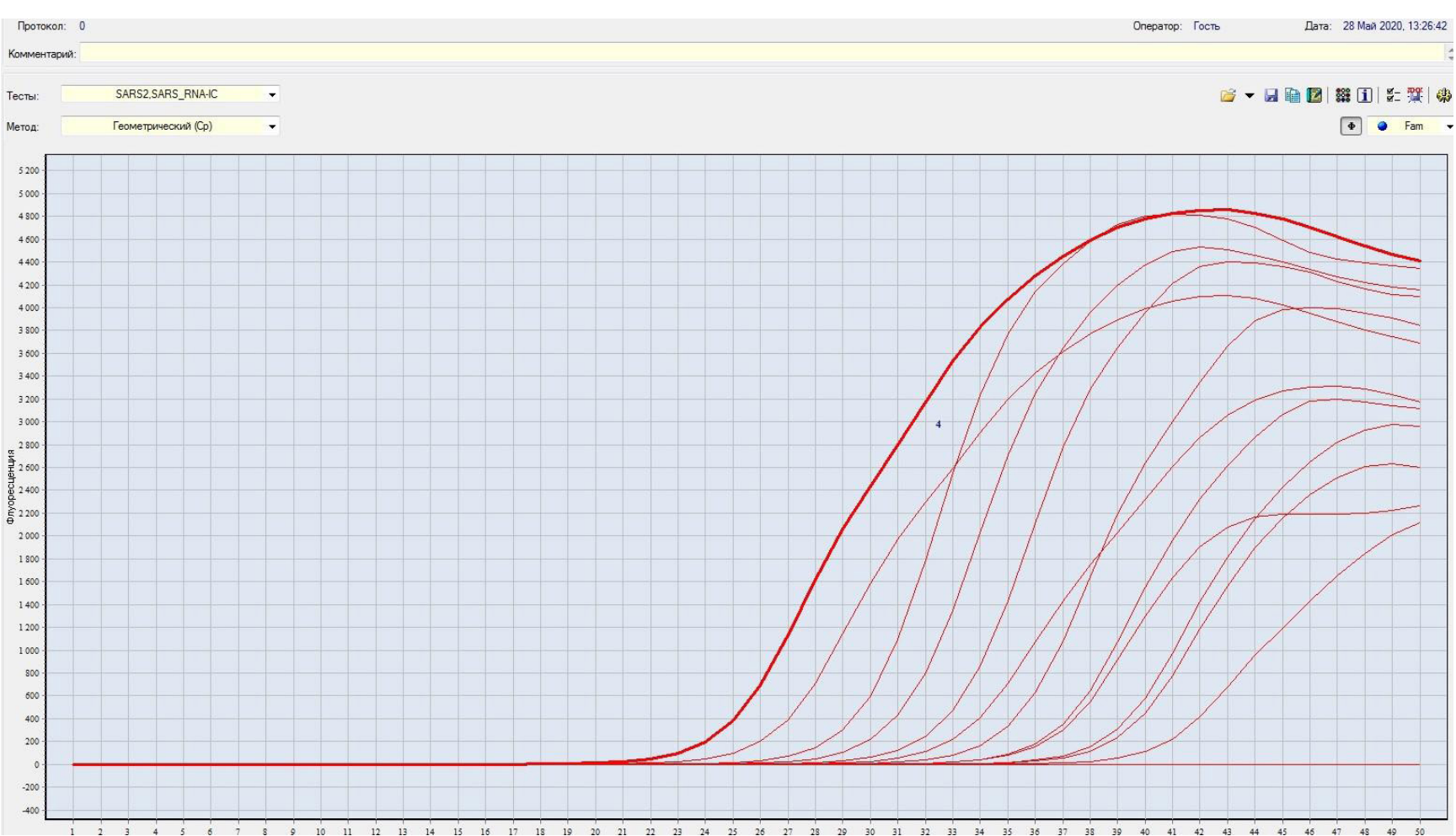

Fig. 1. Early exponential increase in fluorescence intensity in the Fam/Green channels (conserved region of the E gene) in the sample collected on May 28,2020 (day 1 ) 


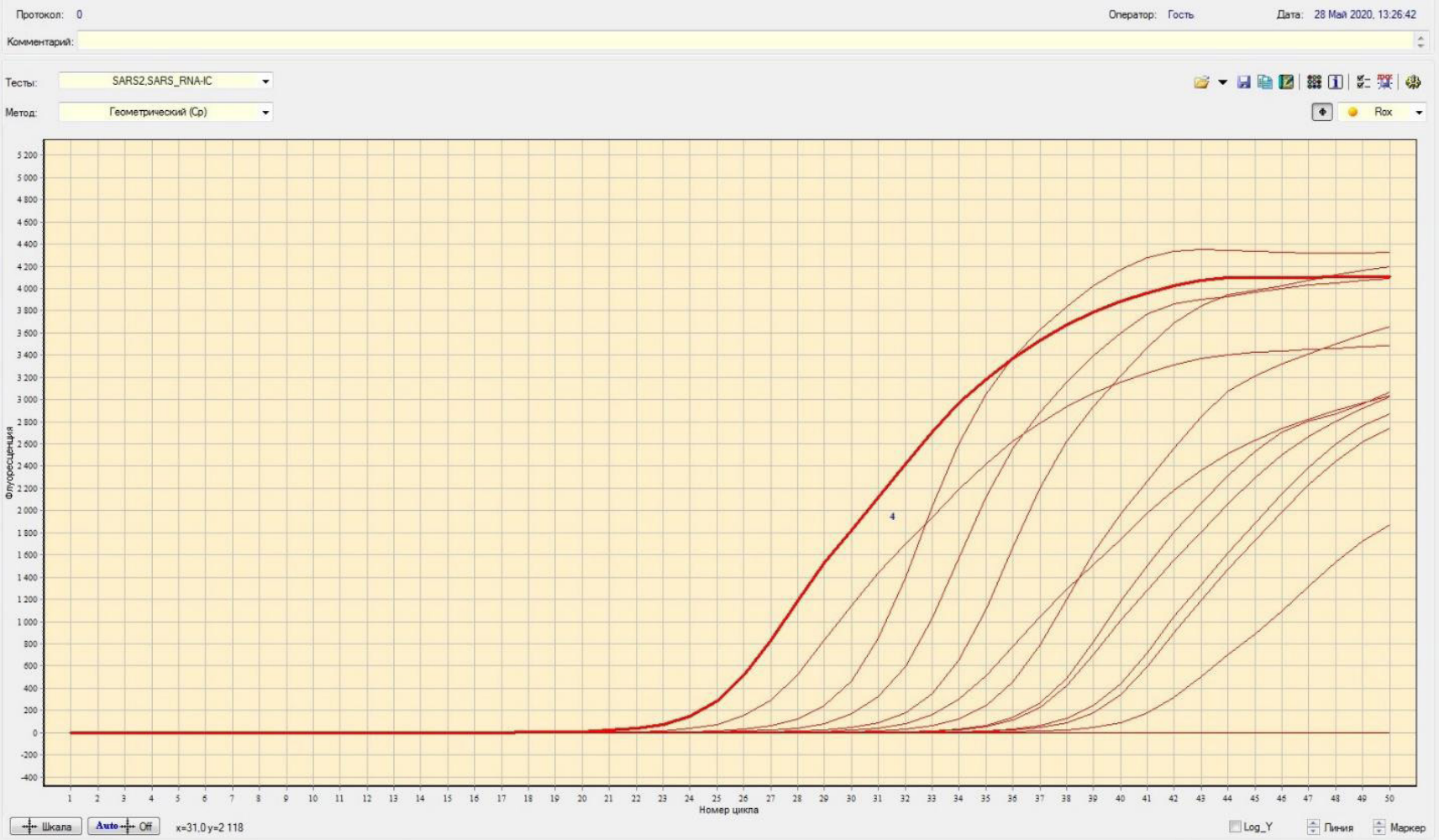

Fig. 2. Early exponential increase in fluorescence intensity in the Rox/Orange channel in the sample collected on May 28, 2020 (day 1)

channel (the E gene of SARS-CoV-2), with $\mathrm{Ct}=37.5$, and the Cy5/Red channel (the $\mathrm{N}$ gene SARS-CoV-2), with $\mathrm{Ct}=38.1$, indicating the presence of SARS-CoV-2 RNA.

In the sample collected on June 9 (day 13), an increase in fluorescence intensity was detected in the Fam/Green channel (SARS-CoV RNA), with Ct = 31.9; the Hex/Yellow channel (IC), with $\mathrm{Ct}=30.0$; the Rox/Orange channel (the E gene of SARSCoV-2), with $\mathrm{Ct}=32.1$; the Cy5/Red channel (the $\mathrm{N}$ gene of SARS-CoV-2), with $\mathrm{Ct}=31.8$, indicating the presence of SARS-CoV-2 RNA.

In the sample collected on June 20 (day 20), an increase in fluorescence intensity was detected in the Fam/Green channel

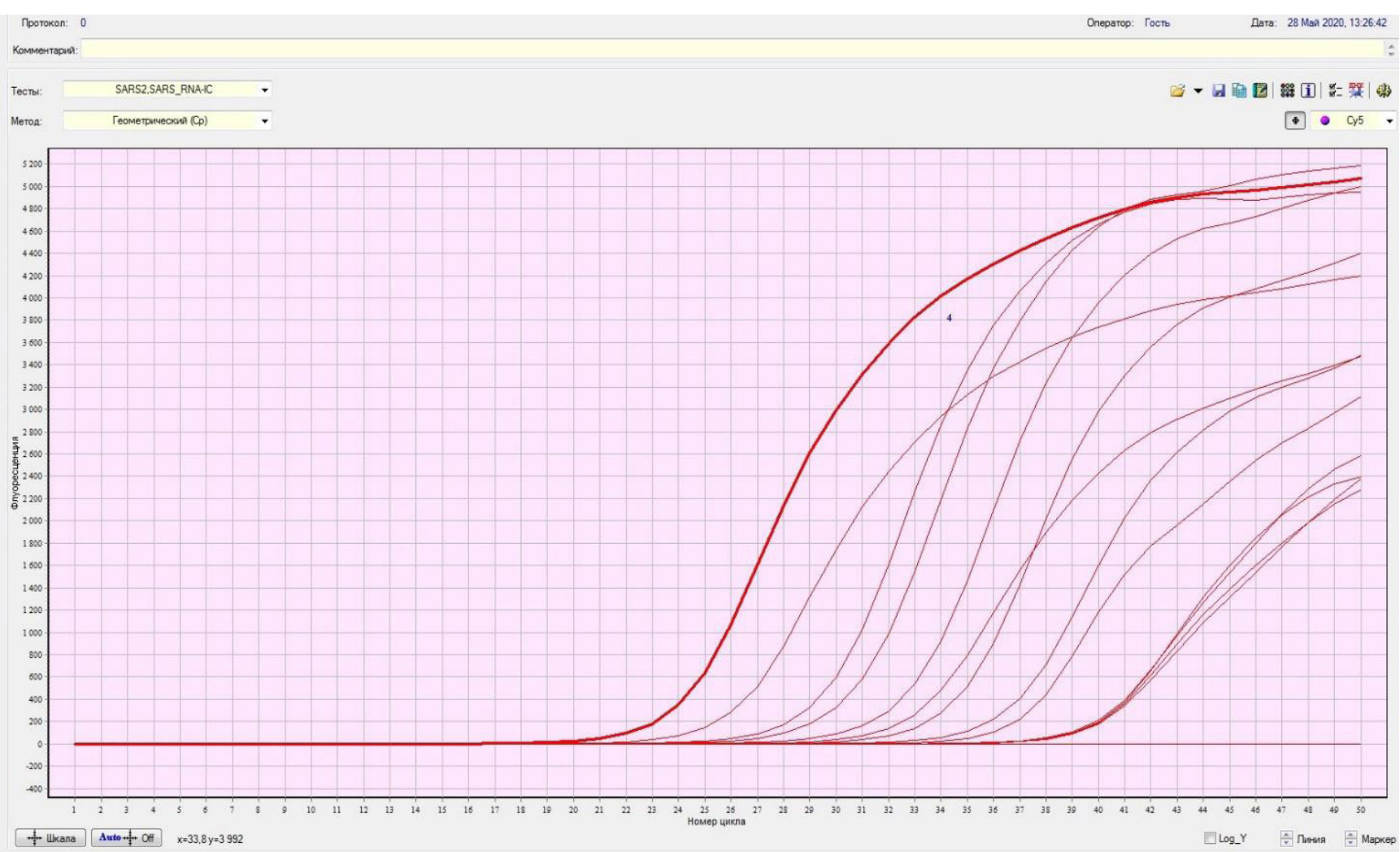

Fig. 3. Early exponential increase in fluorescence intensity in the Cy5/Red channel in the sample collected on May 28, 2020 (day 1) 


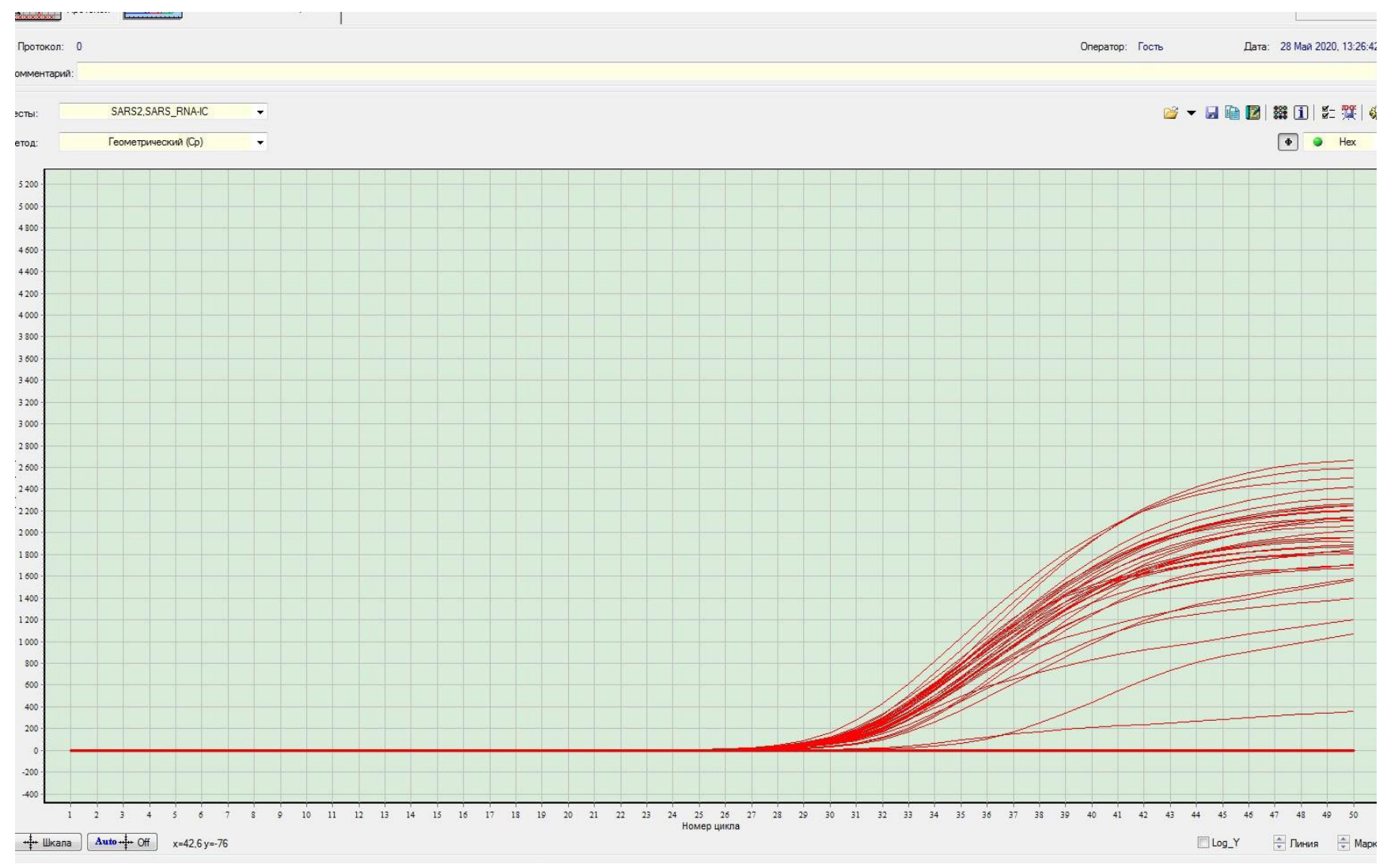

Fig. 4. The absence of the fluorescent signal in the Hex/Yellow channel (the assay included valid positive and negative controls)

(SARS-CoV RNA), with Ct = 34.6; the Hex/Yellow (IC) channel, with $\mathrm{Ct}=31.0$; the Rox/Orange channel (the E gene of SARSCoV-2), with $\mathrm{Ct}=34.5$; the Cy5/Red channel (the $\mathrm{N}$ gene of SARS-CoV-2), with $\mathrm{Ct}=34.7$, indicating the presence of SARS-CoV-2 RNA.

The $\mathrm{E}$ and $\mathrm{N}$ genes of SARS-CoV-2 were detected in each of the 4 studied samples.

Considering the patient's medical history, clinical presentations and the results of laboratory and instrumental tests, the final diagnosis was COVID-19, severe course; community-acquired bilateral polysegmental pneumonia. Given the severity of the patient's condition, she was admitted to the intensive care unit, where she received infusions of sodium chloride $0.9 \%$, amoxicillin, clavulanic acid, moxifloxacin, paracetamol, ascorbic acid, acetylcysteine, omeprazole, bisoprolol, and sodium enoxaparin. After two days, her condition stabilized and she was transferred to the floor. On day 9 , the patient developed moderately itching macular rashes, which tended to coalesce (Fig. 5-7). The patient's overall condition was stable, without deterioration. After completing the full course of the prescribed antibiotics, the patient received intramuscular injections of dexamethasone (16 mg per day) and intramuscular injections of chloropyramine (20 mg twice a day). On day 15, the rashes regressed. A chest CT scan showed improvement. On day 20 the patient was discharged home in satisfactory condition.

\section{Discussion}

So far, there have been a variety of clinical case reports and propositions on the management of patients with CVI $[12,13]$.

Cutaneous manifestations differing in morphology and duration pose a particular interest for a clinician. At the moment, their underlying causes are being investigated. Establishing an accurate etiological diagnosis is essential for working out the right treatment strategy [4].

A study conducted in 88 patients hospitalized for severe CVI reported cutaneous involvement in 18 (20.4\%) participants. Skin manifestations were described by the authors as erythematous rash, widespread urticaria, and chickenpoxlike vesicles; 8 patients had rashes prior to hospitalization, 10 developed them at hospital [14].

There are reports of petechial and purpuric rashes, transient livedo reticularis livedo and acroischemic lesions [15]. A question remains whether these manifestations should be associated with COVID-19 as exanthems are often caused by viral infections or are the adverse reaction to a prescribed drug.

Our female patient was old and had severe CVI and preexisting conditions. On day 9, she developed itchy macular skin eruptions showing a tendency to coalesce. It is difficult to establish an association between cutaneous manifestations, which can be caused by infection or allergy, and COVID-19. According to the literature, cutaneous involvement is observed in patients with COVID-19 starting from day 2 and into the second week of the infection.

Exanthems are an important criterion for differentiating a viral infection from an adverse drug reaction. Because of COVID-19 safety precautions, the physical examination of patients with CVI symptoms does not follow the standard protocol which includes oral cavity examination. For example, of 21 patients with PCR-confirmed COVID-19 and skin rashes, 6 (29\%) had exanthems [15], 4 of 6 (66\%) were women, and none had an erythematovesicular exanthem. The mean time from the onset of COVID-19 symptoms to cutaneous/mucosal manifestations was 12.3 days ( 2 to 24 days). The authors of that study emphasized that rash morphology, other clinical symptoms and the presence of exanthems can help in differentiating between viral and drug-induced skin conditions. The presence 


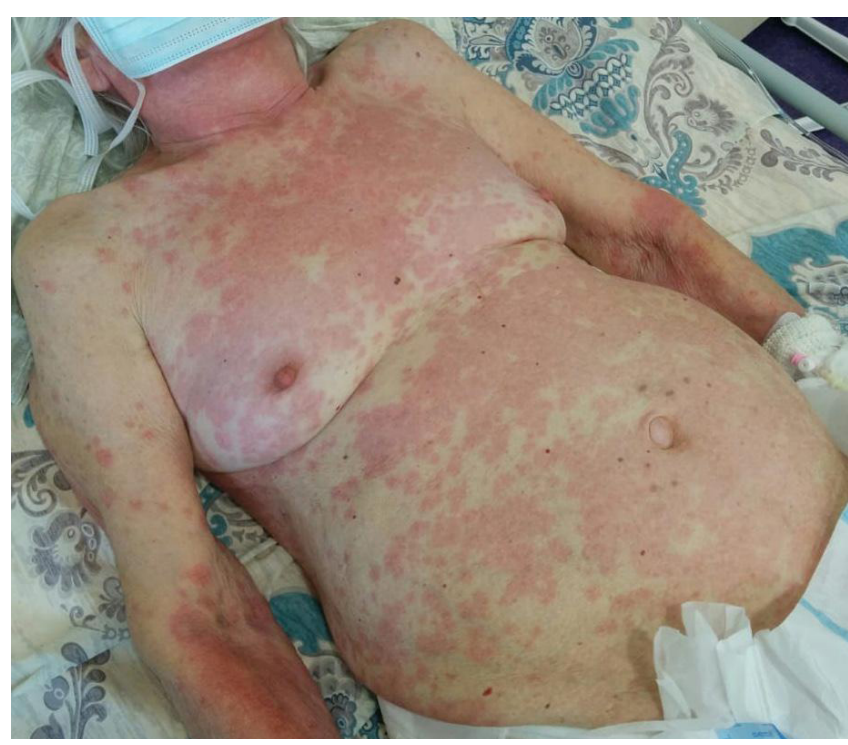

Fig. 5. Macular rashes on the patient's trunk, with a tendency to coalesce. Day 9 into treatment

of pustules and macular spots on the skin suggests an adverse reaction to a prescribed drug, whereas petechias and vesicles localized to the buttocks or the acral parts of the extremities in combination with exanthems are indicative of infection, including viral infection [15]. Some histopathological features of the lesions like parakeratosis, spongiosis, or extravasated erythrocytes, may suggest the viral nature of the condition [16].

The treatment regimen for our patient had to include a number of different drugs, which increased the risk of drug cross-reactivity. Another factor supporting the hypothesis of drug eruptions is that the patient developed rashes after she was put on the regimen that included $\beta$-lactams and fluoroquinolones.

It is possible that cutaneous manifestations may have been associated with a secondary bacterial infection and the compromised immune status of the patient. This hypothesis is supported by the fact that the antigen was detected in the blood samples of the patient through day 20 of the disease, suggesting a weak immune response to the infection. In an aging individual, immunocompetent cells become less active due to involutional changes.

Since high viral load may also be associated with dermatological symptoms, delayed cutaneous manifestations (on day 9) could be regarded as markers of CVI severity, regressing as the patient improved.

\section{CONCLUSIONS}

This clinical case demonstrates the difficulty in the differential diagnosis of cutaneous manifestations in patients with CVI.

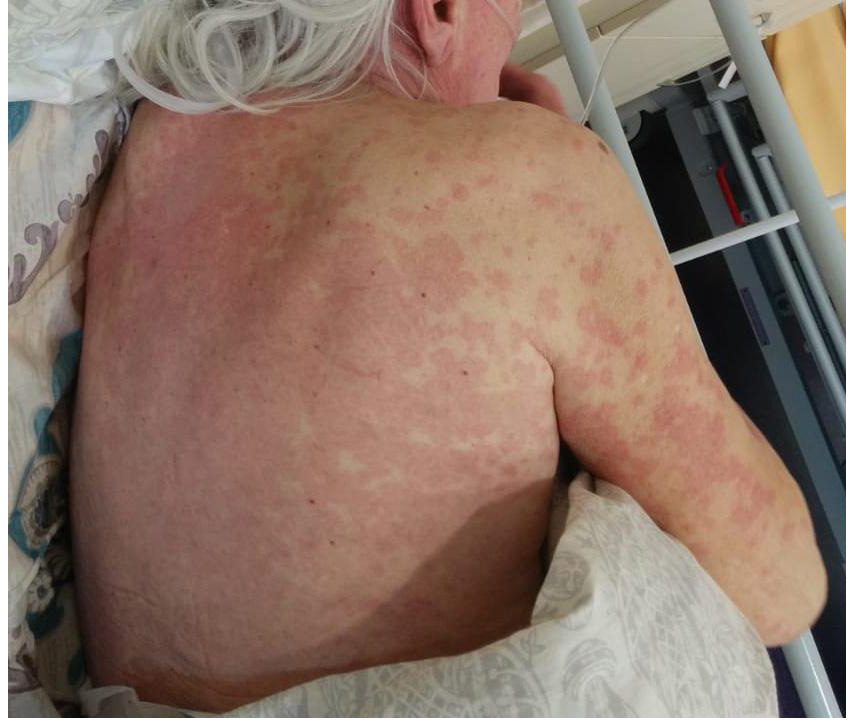

Fig. 6. Macular rashes on the patient's back, with a tendency to coalesce. Day 9 into treatment

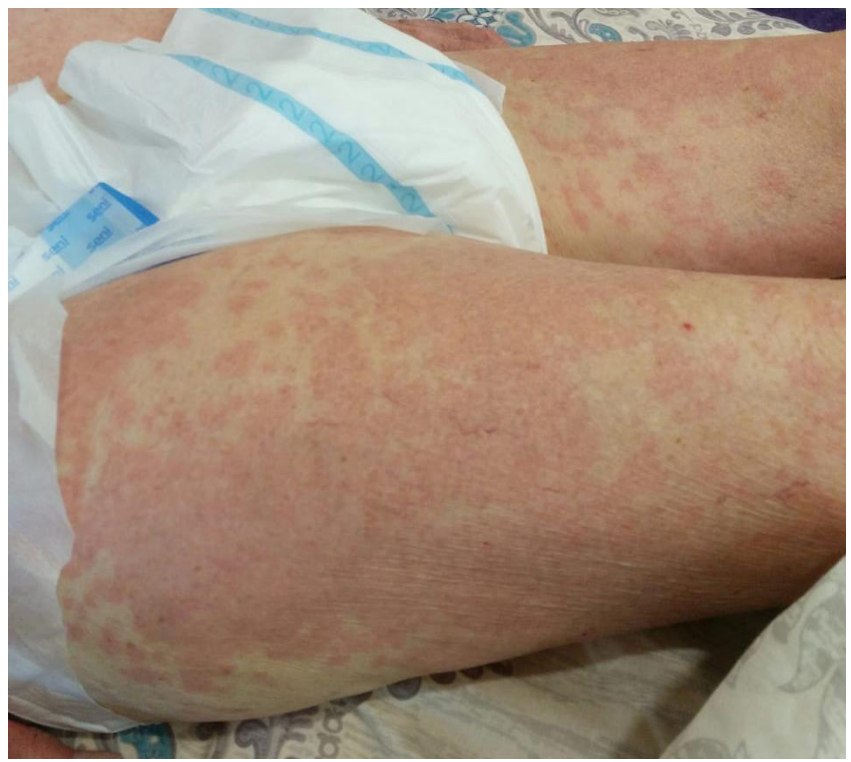

Fig. 7. Macular rashes on the patient's thighs, with a tendency to coalesce. Day 9 into treatment

Their etiology is especially hard to identify in patients with multiple comorbidities requiring complex treatment regimens, which can provoke skin eruptions. Involutional changes accompanied by a decline in the immune function should also be taken into account. Delayed onset of skin symptoms might be regarded as a marker of CVI severity.

\section{References}

1. Casas C, Catala A, Hernandez G, Rodríguez-Jimenez P, Nieto D, Rodriguez-Villa $A$, et al. Classification of the cutaneous manifestations of COVID-19: a rapid prospective nationwide consensus study in Spain with 375 cases. British Journal of Dermatology. 2020; 183 (1): 71-77. DOI: 10.1111/bjd.19163.

2. Almutairi N, Schwartz RA. COVID-2019 with dermatologic manifestations and implications: an unfolding conundrum. Dermatol Therapy. 2020; e13544. Available from: https://doi. org/10.1111/dth.13544.

3. Recalcati S, Barbagallo T, Frasin LA, Prestinari F, Cogliardi A, Provero $\mathrm{MC}$, et al. Acral cutaneous lesions in the time of COVID-19. J Eur Acad Dermatol Venereol. 2020; 34 (8): e346e347. DOI: 10.1111/jdv.16533.

4. Criado PR, Abdalla BMZ, Assis IC, Blarcum de Graaff Mello C, Caputo GC, Vieira IC. Are the cutaneous manifestations during or due to SARS-CoV-2 infection/COVID-19 frequent or not? Revision of possible pathophysiologic mechanisms. Inflamm Res. 2020; 69 (8): 745-56. DOI: 10.1007/s00011-020-01370-w. 
5. Wang C, Horby PW, Hayden FG, Gao GF. A novel coronavirus outbreak of global health concern. Lancet. 2020; 395 (10223): 470-73. DOI: 10.1016/S0140-6736(20)30185-9.

6. Formica D, Sultana J, Cutroneo P, et al. The economic burden of preventable adverse drug reactions: a systematic review of observational studies. Expert Opin Drug Saf. 2018; 17 (7): 68195. DOl: 10.1080/14740338.2018.1491547

7. Aung A, Tang M, Adler N, et al. Adverse Drug Reactions Reported by Healthcare Professionals: Reaction Characteristics and Time to Reporting. The Journal of Clinical Pharmacology. 2018; 58 (10): 1332-9. DOI: 10.1002/jcph.1148.

8. Gelincik A, Brockow K, Celik GE, Dona I, Mayorga C, Romano A, et al. Diagnosis and management of the drug hypersensitivity reactions in Coronavirus disease 19. Allergy. 2020; 10.1111/ all.14439. DOI: 10.1111/all.14439.

9. Marzano AV, Cassano N, Genovese G, Moltrasio C, Vena GA. Cutaneous manifestations in patients with COVID-19: a preliminary review of an emerging issue. British Journal of Dermatology. 2020; 183 (3): 431-42. DOl: 10.1111/bjd.19264.

10. Su CJ, Lee CH. Viral exanthem in COVID-19, a clinical enigma with biological significance. J Eur Acad Dermatol Venereol. 2020; 34 (6): e251-e252. DOI: 10.1111/jdv.16469.

11. Henry D, Ackerman M, Sancelme E, Finon A, Esteve E. Urticarial eruption in COVID-19 infection. J Eur Acad Dermatol Venereol. 2020; 34 (6): e244-e245. DOI: 10.1111/jdv.16472.

\section{Литература}

1. Casas C, Catala A, Hernandez G, Rodríguez-Jimenez P, Nieto D, Rodriguez-Villa $A$, et al. Classification of the cutaneous manifestations of COVID-19: a rapid prospective nationwide consensus study in Spain with 375 cases. British Journal of Dermatology. 2020; 183 (1): 71-77. DOI: 10.1111/bjd.19163.

2. Almutairi N, Schwartz RA. COVID-2019 with dermatologic manifestations and implications: an unfolding conundrum. Dermatol Therapy. 2020; e13544. Available from: https://doi org/10.1111/dth.13544.

3. Recalcati S, Barbagallo T, Frasin LA, Prestinari F, Cogliardi A, Provero $\mathrm{MC}$, et al. Acral cutaneous lesions in the time of COVID-19. J Eur Acad Dermatol Venereol. 2020; 34 (8): e346e347. DOI: 10.1111/jdv.16533.

4. Criado PR, Abdalla BMZ, Assis IC, Blarcum de Graaff Mello C, Caputo GC, Vieira IC. Are the cutaneous manifestations during or due to SARS-CoV-2 infection/COVID-19 frequent or not? Revision of possible pathophysiologic mechanisms. Inflamm Res. 2020; 69 (8): 745-56. DOI: 10.1007/s00011-020-01370-w.

5. Wang C, Horby PW, Hayden FG, Gao GF. A novel coronavirus outbreak of global health concern. Lancet. 2020; 395 (10223): 470-73. DOI: 10.1016/S0140-6736(20)30185-9.

6. Formica D, Sultana J, Cutroneo P, et al. The economic burden of preventable adverse drug reactions: a systematic review of observational studies. Expert Opin Drug Saf. 2018; 17 (7): 68195. DOI: 10.1080/14740338.2018.1491547

7. Aung A, Tang M, Adler N, et al. Adverse Drug Reactions Reported by Healthcare Professionals: Reaction Characteristics and Time to Reporting. The Journal of Clinical Pharmacology. 2018; 58 (10): 1332-9. DOI: 10.1002/jcph.1148.

8. Gelincik A, Brockow K, Celik GE, Dona I, Mayorga C, Romano A, et al. Diagnosis and management of the drug hypersensitivity reactions in Coronavirus disease 19. Allergy. 2020; 10.1111/ all.14439. DOI: 10.1111/all.14439.

9. Marzano AV, Cassano N, Genovese G, Moltrasio C, Vena GA.
12. Tang $K$, Wang $Y$, Zhang $H$, Zheng $Q$, Fang $R$, Sun $Q$. Cutaneous manifestations of the Coronavirus Disease 2019 (COVID-19): A brief review. Dermatol Ther. 2020: e13528. DOI: 10.1111/ dth. 13528.

13. Vremennye metodicheskie rekomendacii 'Profilaktika, diagnostika i lechenie novoj koronavirusnoj infekcii (COVID-19)'. Versija 8.1 (01.10.2020), utverzhdennye Ministerstvom zdravoohranenija RF. Available from: https://static-0.minzdrav.gov.ru/system/ attachments/attaches/000/052/219/original/\%D0\%92\%D1\% 80\%D0\%B5\%D0\%BC\%D0\%B5\%D0\%BD\%D0\%BD\%D1\% 8B\%D0\%B5_\%D0\%9C\%D0\%A0_COVID-19_\%28v.8.1\%29. pdf?1601561462. Russian.

14. Recalcati S. Cutaneous manifestations in COVID-19: a first perspective. J Eur Acad Dermatol Venereol. 2020; 34 (5): e212e213. DOI: 10.1111/jdv.16387.

15. Jimenez-Cauhe J, Ortega-Quijano D, Prieto-Barrios M, MorenoArrones OM, Fernandez-Nieto D. Reply to "COVID-19 can present with a rash and be mistaken for dengue": Petechial rash in a patient with COVID-19 infection. J Am Acad Dermatol. 2020; 83 (2): e141-e142. DOI: 10.1016/j.jaad.2020.04.016.

16. Diaz-Guimaraens B, Dominguez-Santas M, Suarez-Valle A, Pindado-Ortega C, Selda-Enriquez G, Bea-Ardebol S, et al. Petechial Skin Rash Associated With Severe Acute Respiratory Syndrome Coronavirus 2 Infection. JAMA Dermatol. 2020; 156 (7): 820-22. DOI: 10.1001/jamadermatol.2020.1741.

Cutaneous manifestations in patients with COVID-19: a preliminary review of an emerging issue. British Journal of Dermatology. 2020; 183 (3): 431-42. DOl: 10.1111/bjd.19264.

10. Su CJ, Lee CH. Viral exanthem in COVID-19, a clinical enigma with biological significance. J Eur Acad Dermatol Venereol. 2020; 34 (6): e251-e252. DOI: 10.1111/jdv.16469.

11. Henry D, Ackerman M, Sancelme E, Finon A, Esteve E. Urticarial eruption in COVID-19 infection. J Eur Acad Dermatol Venereol. 2020; 34 (6): e244-e245. DOI: 10.1111/jdv.16472.

12. Tang $K$, Wang $Y$, Zhang $H$, Zheng $Q$, Fang $R$, Sun $Q$. Cutaneous manifestations of the Coronavirus Disease 2019 (COVID-19): A brief review. Dermatol Ther. 2020: e13528. DOI: 10.1111/ dth.13528.

13. Временные методические рекомендации «Профилактика, диагностика и лечение новой коронавирусной инфекции (COVID-19)». Версия 8.1 (01.10.2020), утвержденные Министерством здравоохранения РФ. Доступно по ссылке: https://static-0.minzdrav.gov.ru/system/attachments/ attaches/000/052/219/original/\%D0\%92\%D1\%80\%D0\%B5\%D 0\%BC\%D0\%B5\%D0\%BD\%D0\%BD\%D1\%8B\%D0\%B5 \%D0\% 9C\%D0\%A0_COVID-19_\%28v.8.1\%29.pdf?1601561462.

14. Recalcati S. Cutaneous manifestations in COVID-19: a first perspective. J Eur Acad Dermatol Venereol. 2020; 34 (5): e212e213. DOI: 10.1111/jdv.16387

15. Jimenez-Cauhe J, Ortega-Quijano D, Prieto-Barrios M, MorenoArrones OM, Fernandez-Nieto D. Reply to "COVID-19 can present with a rash and be mistaken for dengue": Petechial rash in a patient with COVID-19 infection. J Am Acad Dermatol. 2020; 83 (2): e141-e142. DOI: 10.1016/j.jaad.2020.04.016.

16. Diaz-Guimaraens $B$, Dominguez-Santas $M$, Suarez-Valle $A$, Pindado-Ortega C, Selda-Enriquez G, Bea-Ardebol S, et al. Petechial Skin Rash Associated With Severe Acute Respiratory Syndrome Coronavirus 2 Infection. JAMA Dermatol. 2020; 156 (7): 820-22. DOI: 10.1001/jamadermatol.2020.1741. 